\title{
Effects of glacier retreat on the outbursts of Goësvatnet, southwest Spitsbergen, Svalbard
}

\author{
W. SChÖNER, ${ }^{1}$ M. SchöneR ${ }^{2}$ \\ ${ }^{1}$ Zentralanstalt für Meteorologie und Geodynamik, Klimaabteilung, Hohe Warte 38 A-1190 Vienna, Austria \\ ${ }^{2}$ Institut für Photogrammetrie und Fernerkundung, Technische Universität Wien, Gusshausstrasse 25-29/122 A-1040 Vienna, Austria
}

\begin{abstract}
Effects of the retreat of Gåsbreen, southwest Spitsbergen, Svalbard, on the evolution of the ice-dammed lake Goësvatnet are shown for the period 1899-1991. The retreat and lowering of the damming ice masses have changed not only the stored lake volume, the lake geometry and the elevation, slope and length of the subglacial outlet tunnel, but also the frequency and magnitude of outburst floods of Goësvatnet. For the estimation of peak discharges of outburst floods we computed an unbiased regression equation related to the progressive enlargement of subglacial tunnels using lake volume data and peak discharge data from the literature. The derived equation is very similar to the original form of the Clague-Mathews formula and answers the question why this formula has worked well in many cases. Peak discharges of Goësvatnet in various years were estimated by means of the derived equation. Effects of the changed lake geometry as well as the changed length and slope of the subglacial outlet tunnel on the discharge during outbursts will be discussed by means of the Nye-Clarke model. Observation of an outburst of Goësvatnet in summer 1991 indicates that the outbursts may have been triggered by pressure decrease in the subglacial outlet tunnel during increased discharge, whereas flotation of the ice dam can be excluded.
\end{abstract}

\section{INTRODUCTION}

Outbursts of glacier-dammed lakes are well-known phenomena of the glacier landscape. Due to the rapid drainage process during such outbursts and the damage to cultivated areas known from recent and former outbursts, they are of great importance to glaciological research. The magnitude and frequency of outbursts of glacier-dammed lakes are in close correlation to the oscillations of the damming ice masses (e.g. Liestøl, 1956).

The aim of this paper is to show the effects of the retreat of Gåsbreen, southwest Spitsbergen, Svalbard, on the periodic outbursts of Goësvatnet. The retreat of the glacier during the 20th century has changed the geometry of the damming ice masses as well as the geometry of the lake, the lake volume and the tunnel system used for the outbursts. Using an empirical formula, the effect of the changed lake volume on the peak discharge of outbursts will be investigated, whereas the effects of the changed ice-dam geometry, lake geometry and outlet tunnel system will be shown by means of a physically based model (Clarke, 1982). The retreat of Gasbreen and the evolution of Goësvatnet since 1899 are well documented by various aerial photos, maps and field observations. It is also the aim of this study to show that a qualitative and quantitative description of historical outbursts of glacier-dammed lakes can be given without discharge measurements but by using a physically based model and careful interpretation of old maps, aerial photos and field observations.

Goësvatnet is a marginal ice-dammed lake (Fig. 1), which in 1991 was $30 \mathrm{~m}$ deep and covered an area of about $0.5 \mathrm{~km}^{2}$. It is dammed by the active and stagnant ice of
Gåsbreen, a temperate valley glacier (Fig. 1). A detailed description of the evolution of Gåsbreen and Goësvatnet since 1938 can be found in Schöner and Schöner (1996). Outbursts of the lake have been presumed since 1938 (Pillewizer, 1939) and have been known since 1956 (Grzés and Banach, 1984). The first direct observation of a jökulhlaup of Goësvatnet was made by the authors of this study during an expedition in summer 1991.

\section{EVOLUTION OF GÅSBREEN AND GOËSVATNET IN THE PERIOD 1899-1991}

The first evidence of the lake is in a map made by De Geer in 1899 (De Geer, 1925). At that time the lake was dammed by the ice masses of Goësbreen which formed a confluence with Gåsbreen in the area of the lake. Various maps (De Geer, 1925; Pillewizer, 1939; Polska Akademia Nauk, 1987; Schöner and Schöner, 1996) show that the ice dam was thinned by about $100 \mathrm{~m}$ between 1899 and 1990. Due to this fact and the lack of ice supply for the damming ice masses, the lake moved north and the maximum water level sank from about 150 to $68 \mathrm{~m}$ a.s.l. (Fig. 1).

The formation of these substantial damming ice masses in previous years can be explained by: (1) favourable climatic conditions in this period (Brazdil and others, 1988) permitting such an advanced state of the glacier; (2) a surge (or kinematic wave) of the glacier in an earlier time period (Baranowski, 1977).

The evolution of Goësvatnet since 1899 documented by maps, aerial photos and field observations is compiled in Table 1 . In most of the cases the field observations are, however, related only to the filling condition of the lake. 


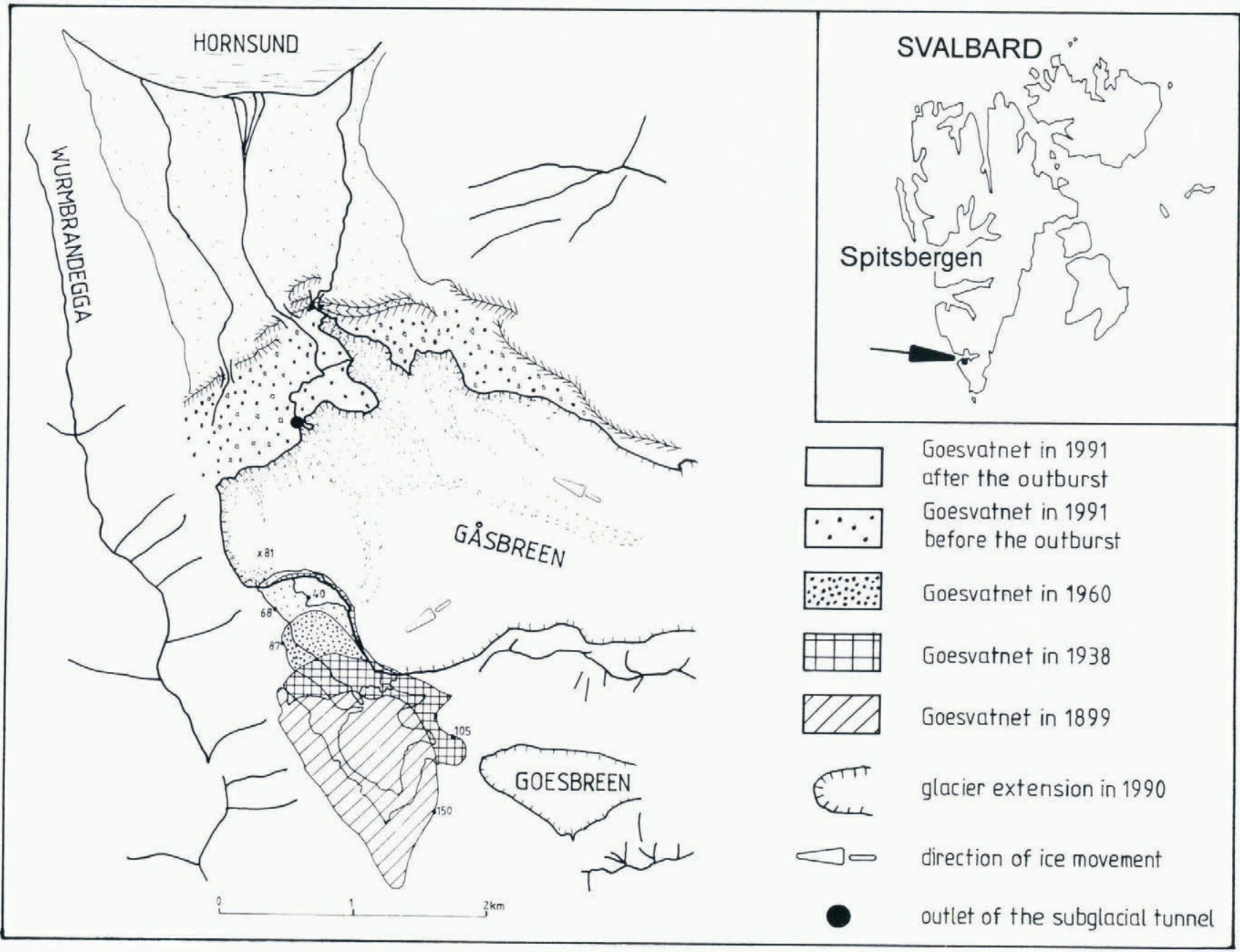

Fig. 1. Map showing the location of Gäsbreen and the situation of the ice-dammed lake Goësvatnet in various years.

It can be seen from Table 1 that on aerial photos taken in 1961 and 1990 the lake is visible in an empty state. Photogrammetric interpretation of these aerial photos enables

Table 1. Information and observations about the condition of the ice-dammed lake Goësvatnet for the time period 1899-1991

Date $\begin{gathered}\text { Filling } \\ \text { condition }\end{gathered}$ Lakelevel Source

ma.s.l.

\begin{tabular}{|c|c|c|c|}
\hline 1899 & Filled & 150 & De Greer 1925 \\
\hline 1936 & Filled & 115 & Topographic chart, 1948 \\
\hline 1938 & Filled & 105 & Pillewizer (1939) \\
\hline 1956 & Empty & & Grzés and Banach (1984) \\
\hline 1959 & Filled & & Grzés and Banach (1984) \\
\hline 1960 & Filled & 94 & Norsk Polarinstitutt (1990) \\
\hline 1961 & Empty & & Norsk Polarinstitutt $(1990)$ \\
\hline 1970 & Filled & & Grzés and Banach (1984) \\
\hline 1975 & Filled & & Grzés and Banach (1984) \\
\hline 1977 & Filled & & Grzés and Banach (1984) \\
\hline 1978 & Empty & & Grzés and Banach (1984) \\
\hline April 1979 & Empty & & Grzés and Banach (1984) \\
\hline July 1979 & Filled & 87 & Grzés and Banach (1984) \\
\hline July 1980 & Filled & 87 & Grzés and Banach (1984) \\
\hline August 1980 & Empty & & Grzés and Banach (1984) \\
\hline July 1981 & Empty & & Grzés and Banach (1984) \\
\hline August 1982 & Filled & & Jania (personal communication, 1993 \\
\hline August 1988 & Empty & & Jania (personal communication, 1993 \\
\hline August 1990 & Empty & 40 & Norsk Polarinstitutt 1990 \\
\hline July 1991 & Filled & 68 & \\
\hline August 1991 & Empty & 40 & \\
\hline
\end{tabular}

mapping of the bottom topography of the lake Schöner and Schöner, 1996). In a next step the volume of Goësvatnet can be computed for those years when the extension of the lake is shown on large-scale maps, namely, for 1938, 1961 and 1990.

For the purposes of investigating outburst floods of Goësvatnet, the maximum lake volume at the initial state of outbursts is of interest. For the outburst of Goësvatnet in 1991 the maximum lake level is known from direct observation, whereas the topography of the lake is taken from the 1990 map. An outburst in summer 1961 can be derived from an aerial phote taken in 1961 showing Goësvatnet in an empty state and the maximum extension of the lake in a very accurate way by the extension of mud. Based on this information the maximum lake volume in 1961 could be derived from the known lake topography and the extension of mud.

An outburst around 1938 is not known for certain, but it was presumed by Pillewizer (1939). Indications for his assumption were field observations during an expedition in 1938. Due to flood events the sandur plain was free of vegetation, whereas terraces and moraines were vegetated. Moreover, the frontal moraines in the area of the damming ice masses of Gåsbreen showed a well-developed breach which was drained only by a very small river during the summer of 1938. The dimensions of the breach indicate, however, that is was sometimes drained by a much larger amount of water. Shorelines of Goësvatnet showed that the maximum lake level was not higher than about $130 \mathrm{~m}$ a.s.l. at this time (Pillewizer, 1939). Using these observations, the 
map of 1938 (Pillewizer, 1939) and the lake topography derived from the map of 1990 an estimation of the maximum lake volume was possible.

There is no hint of outbursts of Goësvatnet around 1899. Pillewizer (1939) reports that the highest shoreline of Goësvatnet was found at $143 \mathrm{~m}$ a.s.l. which fits rather well with a lake level of $150 \mathrm{~m}$ a.s.l. shown in De Geer's map in 1899 (De Geer, 1925). Furthermore, a great alluvial fan on the orographical lefthand side of the marginal zone in the area of the glacier's frontal moraines can be seen from this map. This possibly indicates an episodic drainage of the lake through a channel in the marginal area of the damming ice masses of Gassbreen for the period around 1899. Due to the lower accuracy of De Geer's map the lake volume was not computed for 1899 .

The computed lake volumes of Goësvatnet for individual years are shown in Table 2. The topography of the lake

Table 2. Topographic parameters derived from interpretation of aerial photos and maps for outbursts of Goësvatnet in various years. 1991 data are based on interpretation of aerial photos taken in 19.90 and on field observations; 1961 data are based on interpretation of aerial photos taken in 1960 and 1961

\begin{tabular}{|c|c|c|c|c|}
\hline & 1899 & 1938 & 1961 & 1991 \\
\hline Length of outlet tunnel, $l_{0}(\mathrm{~m})$ & 2500 & 2000 & 1750 & 1350 \\
\hline Ice thickness at seal, $h_{\mathrm{j}}(\mathrm{m})$ & $140-150$ & $110-120$ & 105 & 50 \\
\hline $\begin{array}{l}\text { Lake level around seal at } \\
\text { initial stage of the }\end{array}$ & & & & \\
\hline $\begin{array}{l}\text { outburst, } h_{0}(\mathrm{~m}) \\
h_{0} / h_{\mathrm{i}}\end{array}$ & $85 ?$ & $\begin{array}{l}70-95 \\
\approx 0.75\end{array}$ & $\begin{array}{c}65 \\
0.62\end{array}$ & $\begin{array}{c}33 \\
0.66\end{array}$ \\
\hline Elevation of tunnel outlet $(\mathrm{m})$ & & 40 & 30 & 22 \\
\hline $\begin{array}{l}\text { Slope of sub-glacial outlet } \\
\text { tunnel, } s\end{array}$ & & 0 & 0.006 & 0.012 \\
\hline Lake volume $V_{0}\left(\mathrm{~m}^{3}\right)$ & & $38480000^{*}$ & 23880000 & 7117500 \\
\hline Lake area $S_{0}\left(\mathrm{~m}^{2}\right)$ & & $1346000^{*}$ & 1132000 & 420000 \\
\hline Geometric parameter $M$ & & 0.340 & 0.325 & 0.513 \\
\hline
\end{tabular}

* Computed for the most likely value of lake level around seal at the initial stage of the outburst derived from field observations (Pillewizer, 1939). in 1938, 1961 and 1990 is shown in Figure 2 and is also described in Table 2 by means of a geometric function in the form of:

$$
\frac{2 h_{\mathrm{w} t}}{h_{0}}=\left(\frac{V_{t}}{V_{0}}\right)^{M}
$$

where $h_{\mathrm{w} t}$ is lake elevation at time $t, h_{0}$ is lake elevation at the start of the outburst, $V_{t}$ is lake volume at time $t, V_{0}$ is lake volume at the start of the outburst, and $M$ is a geometric function.

It can be seen from Table 2 that Goësvatnet changed its geometry from a cone-shaped reservoir in 1938 and 1961 to a paraboloid-shaped reservoir in 1991. The agreement between the lake geometry computed by the geometric function and the geometry derived from a map is shown in Figure 3 for 1938.

Table 2 also includes values of ice thickness in the vicinity of the seal, and the lake level above the seal at the initial stage of outbursts. The relation between these two values is of interest in the investigation of the triggering mechanism of the outbursts. For 1938 the seal is assumed to be in the area of maximum ice thickness of the dircct junction line between the moraine's breach and the lake. The bottom topography of the glacier in 1938 is known from the map of 1990 showing this zone free of ice due to glacier retreat, whereas the glacier surface in 1938 is known from the 1938 map. For the outbursts in 1961 and 1991 the inlet and the outlet of the subglacial tunnel were bound to the border between the active and stagnant part of Gasbreen marked by a medial moraine. The bottom topography of the glacier in 1961 and 1991 has been extrapolated from the region free of ice, and the glacier surfaces are known from the maps. So the seals in 1961 and 1991 were chosen in the area of maximum ice thickness of the medial moraine.

It can be seen from Table 2 that the ratio of ice thickness to water height at the seal is much too high to make possible a flotation of the damming ice masses of Gåsbreen. This indicates another triggering mechanism for the outbursts of Goësvatnet. It is a well-known feature of jökulhlaups of

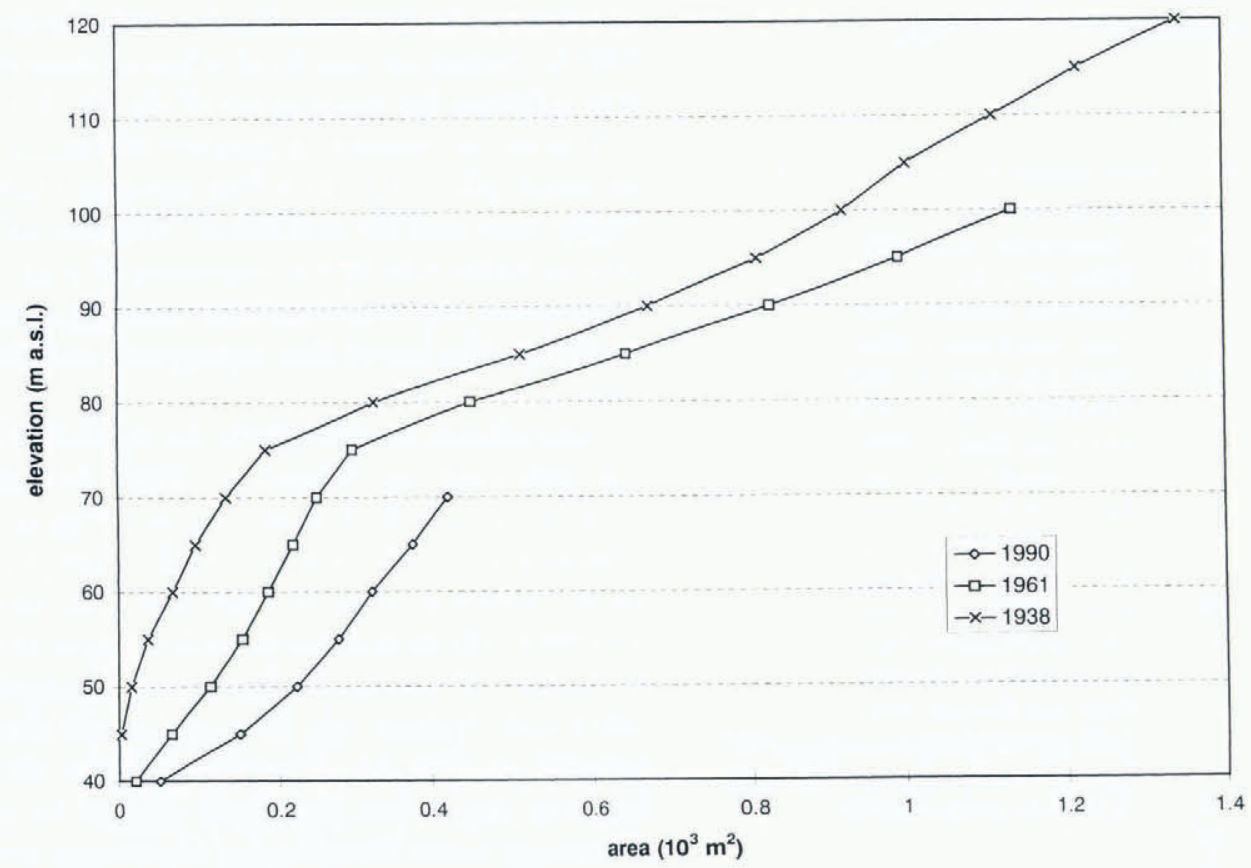

Fig. 2. Bottom topography of Goësvatnet in 1938, 1961 and 1991 derived from interpretation of contour maps. 


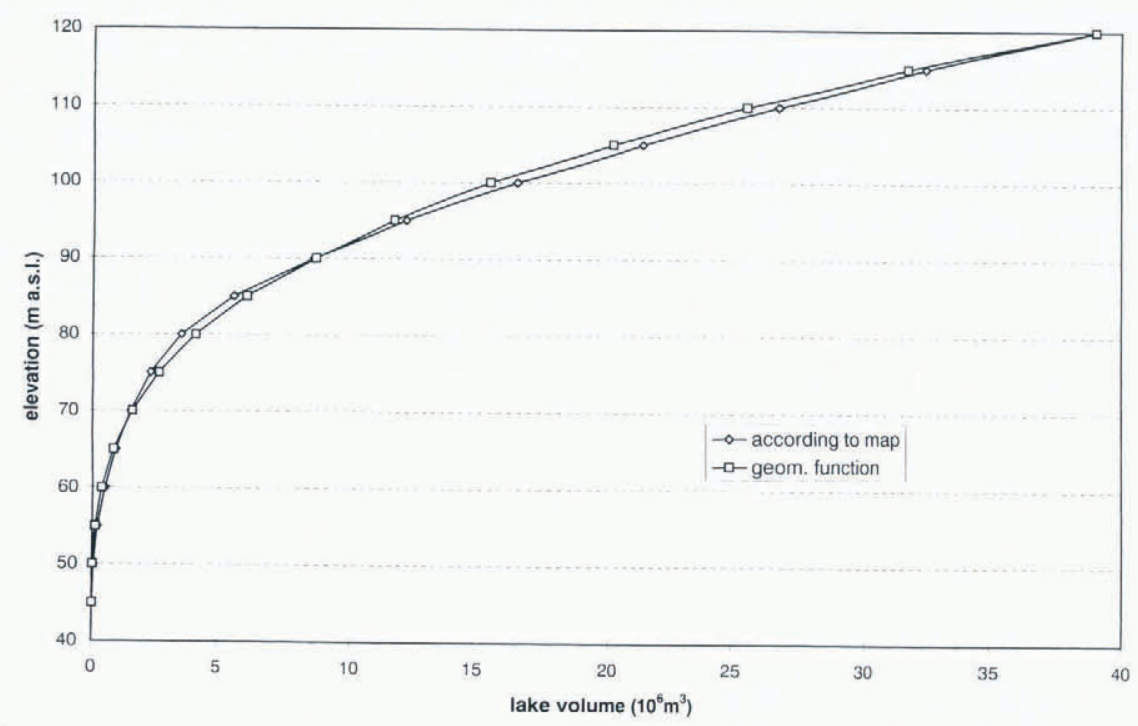

Fig. 3. Lake volume of Goësvatnet in relation to the lake level in 1938 estimated by interpretation of a contour map and by means of a geometric function.

marginal ice-dammed lakes that they start long before flotation is possible (e.g. Fisher, 1973; Björnsson, 1992).

The subglacial outlet tunnel used around 1938 and in 1961 and 1991 is characterised by the length and slope of the tunnel in Table 2. Due to the retreat of Gassbreen the length of the tunnel was reduced by about $35 \%$ between 1938 and 1991. In the same period the slope of the outlet tunnel downstream of the seal changed from about horizontal to 0.012 (Table 2).

It is also evident that the lowering of the ice dam has changed the local climatic conditions of the ice dam, as in general at lower altitudes the ice ablation will be increased. This leads to a feedback mechanism for the thinning of the damming ice masses.

\section{OBSERVED OUTBURST IN 1991}

At the end of July 1990 the lake was nearly empty (aerial photo, 1990). Within 1 year the lake filled again and the water level rose to the height necessary for the beginning of an outburst (68 ma.s.l.) on 24 July 1991 (Fig. 4). Then the outburst started, and the lake lost $7117500 \mathrm{~m}^{3}$ of water within $1.5 \mathrm{~d}$. The lost lake volume was derived from an interpretation of the 1990 contour map. Goësvatnet lost its water through one tunnel between the active and the stagnant

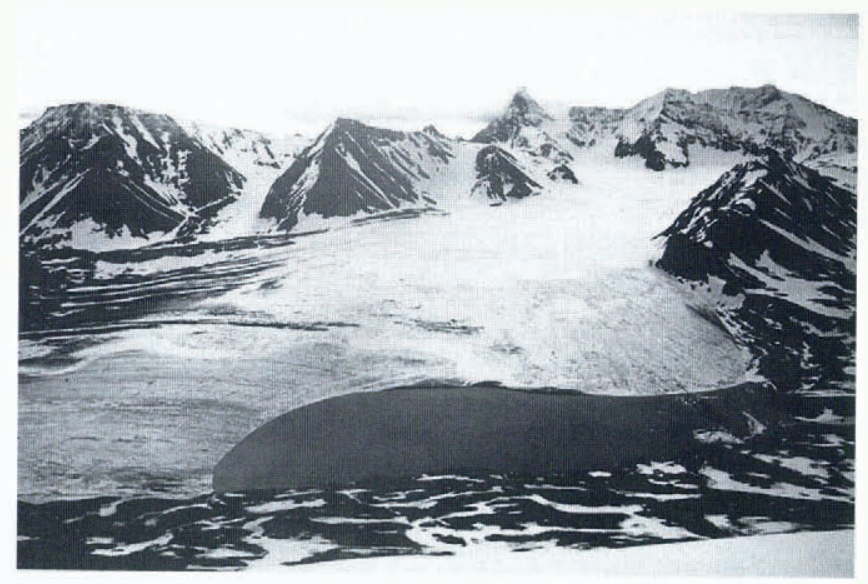

Fig. 4. Goësvatnet before the outburst on 24 July 1991. part of Gåsbreen (Fig. 5). The inlet and the outlet of the tunnel were easy to identify during the fieldwork. The outburst of Goësvatnet led to an increased outflow of the main proglacial river but did not flood the sandur plain. Due to higher river discharge and sediment transport capacity, a large brown fan formed in the sea. After the outburst the situation was quite similar to the one in 1990 with a more or less empty lake (Fig. 6).

The outburst of Goësvatnet in 1991 started after a period of strong ablation due to high air temperature and intensive

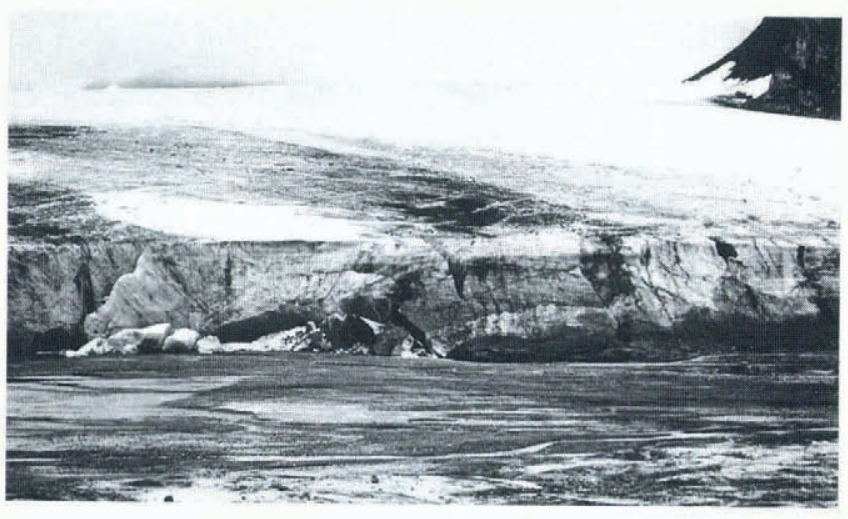

Fig. 5. Outlet tunnel of the 1991 outburst of Goësvatnet at the border between the active and stagnant ice of Gaisbreen.

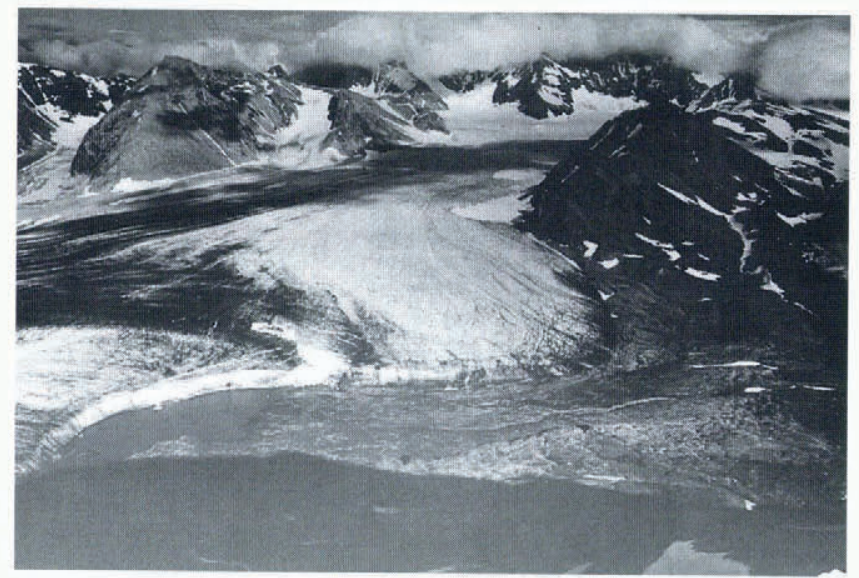

Fig. 6. Goësvatnet after the 1991 outburst. 
radiation. So in our opinion the initial stage of the outburst in 1991 was triggered by the pressure decrease during increased discharge in subglacial channels (Röthlisberger, 1972) resulting from intensified ablation. Moreover, at the same time the amount of water stored in the lake was increased, causing higher water pressure in the vicinity of the seal.

\section{TOOLS FOR COMPUTATION OF JÖKULHLAUP DISCHARGE}

An effective tool for the estimation of peak discharge of jökulhlaups is the empirical formula of Clague and Mathews (1973).

$$
Q_{\max }=75 V_{0}^{0.67}\left(r^{2}=96 \%\right)
$$

where $Q_{\max }$ is the maximum discharge in $\mathrm{m}^{3} \mathrm{~s}^{-1}$ and $V_{0}$ is the initial volume of the lake in $10^{6} \mathrm{~m}^{3}$. This regression formula was reworked by several investigators, who included more data points for the relation. The form of the relation proposed by Costa (1988) is

$Q_{\max }=113 V_{0}^{0.64}\left(r^{2}=80 \%\right.$; s.e. $=0.42 \log -\log$ units $)$.

Desloges and others (1989) showed an unbiased form for this $\log -\log$ relation:

$$
Q_{\max }=179 V_{0}^{0.64} .
$$

In our investigation we excluded those data points of the relation where jökulhlaups were related to the "sudden break" of the ice dam, as suggested by Haeberli (1983). We also excluded data points of jökulhlaups which were not related to subglacial drainage. For this "progressive enlargement" relation which is also relevant for the outbursts of Goësvatnet we have found:

$$
Q_{\max }=65 V_{0}^{0.70}\left(r^{2}=93 \% \text {; s.e. }=0.20 \log -\log \text { units }\right)
$$

and for the unbiased form:

$$
Q_{\max }=72 V_{0}^{0.70}
$$

(outburst discharge data extracted from Clague and Mathews (1973), Clarke (1982), Haeberli (1983), Costa (1988), Russell (1989) and Björnsson (1992); number of cases = 17). This data set is more homogeneous and shows a higher coefficient of correlation between the lost lake volume and the peak discharge compared to the data set of Costa (1988). One can see that the derived equation is very similar to the original Clague Mathews formula. Various field observations have shown that outburst floods of glacier-dammed lakes are very often related to progressive enlargement of subglacial outlet tunnels. Due to this fact the similarity between our regression equation and the original ClagueMathews formula explains why the unbiased formula has worked well in many cases.

An alternative method for estimating the peak discharge of the proglacial river is based on the continuity equation and the Manning-Stickler relation (slope-area method; Desloges and others, 1989).

$$
Q_{\max }=\frac{R^{\frac{2}{3}} S^{\frac{1}{2}} A}{0.038 D^{0.167}}
$$

where $R$ is hydraulic radius $(\mathrm{m}), S$ is bed slope for a $100 \mathrm{~m}$ channel reach, $A$ is cross-sectional area $\left(\mathrm{m}^{2}\right)$, and $D$ is average intermediate axis $(\mathrm{m})$ of the ten largest particles in the river-bed.

A third approach for discharge computation of outburst floods is to use physically based models (e.g. Nye, 1976; Spring and Hutter, 1981; Clarke, 1982). Nye (1976) and Clarke (1982) developed a model based on tunnel geometry, continuity, energy conservation and heat transfer with:

$$
Q=f\left[h_{\mathrm{i}}, z_{0}, L_{0}, Q_{\mathrm{i}}, n^{\prime}, \theta_{1}, V\left(h_{\mathrm{w}}\right)\right]
$$

where $h_{\mathrm{i}}$ is ice thickness at the seal, $z_{0}$ is initial lake elevation above the tunnel outlet, $L_{0}$ is drainage tunnel length, $Q_{\mathrm{i}}$ is water inflow to the lake, $n^{\prime}$ is Manning roughness coefficient, $\theta_{\mathrm{l}}$ is lake water temperature, and $V\left(h_{\mathrm{w}}\right)$ is lake volume distribution with depth.

Contrary to the empirical formula of Clague and Matthews the Nye-Clarke model enables the investigation of the effects of changed physical parameters like the lake geometry or a changed subglacial tunnel system on the discharge curve in addition to peak discharge computations (Clarke, 1982).

\section{EFFECTS OF GLACIER RETREAT ON DISCHARGE DURING OUTBURSTS OF GOËSVATNET}

Effects of glacier retreat on the outbursts of glacier-dammed lakes have been discussed in the literature for a long time. Thórarinsson (1939) described ice-dammed lakes of Iceland and their values as indicators of glacier oscillations in historical times. The effect of glacier oscillation on the stored lake volume and the magnitude of outbursts of a glacierdammed lake was first discussed in detail for a Norwegian lake in a paper by Liestøl (1956). Liestøl showed the evolution of an ice-dammed lake from the initial state of the lake to the first outbreak in 1941 and the almost annual flooding since then. This paper was followed by various descriptions of glacier oscillation and outbursts of ice-dammed lakes for other locations. Existing knowledge about the relation between climatic change (and the resulting glacier oscillation) and jökulhlaup activity was summarised in a paper by Evans and Clague (1994). They showed a typical jökulhlaup activity of glacier-dammed lakes in western Canada which seems to agree with our observations and computations for the outbursts of Goësvatnet. At the beginning (in the 19th century and maybe earlier) the lake impounded by the glacier was stable and drained via a stable overflow channel. In the following time period (about the turn of the century) the lake overflowed along the margin of the glacier. Thereafter (about the beginning of the 20th century), sporadic or cyclic flooding started and the glacier retreated until it was no longer able to impound the lake.

Based on our slightly altered form of the Clague-Mathews formula, the peak discharge of jökulhlaups of Goësvatnet in 1991, 1961 and around 1938 was computed (Table 3). It can be seen that the $82 \%$ reduction of the lake volume resulting from the lowering of the damming ice masses is

Table 3. Results of the computed discharge of the jökulhlaups of Goësvatnet in various years

$19381961 \quad 1991$

$\begin{array}{llll}\text { Peak discharge }\left(\mathrm{m}^{3} \mathrm{~s}^{-1}\right) \text { (unbiased Clague-Mathews) } & 926 & 664 & 284 \\ \text { Peak discharge }\left(\mathrm{m}^{3} \mathrm{~s}\right) \text { (Nye-Clarke model) } & 970 & 720 & 240 \\ \text { Max. cross section of outlet tunnel }\left(\mathrm{m}^{2}\right) & 207 & 155 & 72 \\ \text { Duration of outburst }(\mathrm{d}) & \approx 2 & 1 \frac{1}{2} & 1 \frac{1}{3}\end{array}$


equivalent to about a $75 \%$ reduction of the peak discharge for the same time period 1938-91.

A rough check on the computed peak discharge in 1991 was possible by estimating the peak discharge of the proglacial river $1 \mathrm{~km}$ downstream of the frontal moraines by means of the slope area method. Our field observations showed that

$$
A<60 \mathrm{~m}^{2}, R \approx 1.8 \mathrm{~m}, S=0.013, D \approx 1 \mathrm{~m}
$$

From these data we computed a peak discharge of $<270 \mathrm{~m}^{3} \mathrm{~s}^{-1}$ which is in good agreement with that computed for the 1991 jökulhlaup by the unbiased Clague-Mathews formula. But one has to take into account that an agreement between the peak discharge of the subglacial channel and the peak discharge of the proglacial river is not really necessary as water can be stored behind the frontal moraines of Gåsbreen.

The computed peak discharge of $970 \mathrm{~m}^{3} \mathrm{~s}^{-1}$ for a jökulhlap around 1938 confirms the assumption of Pillewizer (1939) that at that time the sandur plain was flooded during an outburst, as the maximum capacity of the proglacial river is less than about $400-500 \mathrm{~m}^{3} \mathrm{~s}^{1}$ (computed by means of the slope-area method).

As mentioned in a previous section, the retreat of the damming ice masses also changed the length and elevation of the subglacial drainage tunnel used for the outbursts in the period 1938-91. Moreover, the lake geometry changed due to the "wandering" of the lake towards north and due to the lowering of the ice dam. The effects of these changed parameters on the peak discharge of the outbursts of Goësvatnet can be shown by means of the Nye-Clarke model. For the simulation of outbursts of Goësvatnet, data of lake geometry, ice thickness at seal, drainage tunnel length, and lake elevation above the seal are known for 1991, 1961 and 1938, whereas the values of lake temperature and the Manning roughness coefficient are unknown. All other physical parameters used for the model were chosen according to values common in the literature (see Clarke, 1982). As $Q_{\mathrm{i}}$ is very small compared to $Q$ this parameter was neglected.

For the outburst of Goësvatnet in 1991 a rough value of the duration of the outburst is known from direct observation $(1.5 \mathrm{~d})$. Based on this observation the values of lake temperature and Manning roughness were estimated by iterative derivation using the Nye-Clarke model. A value of $n=0.070 \mathrm{~m}^{-1 / 3} \mathrm{~s}$ and a lake temperature of $6^{\circ} \mathrm{C}$ leads to a duration of the outburst of $32 \mathrm{~h}$, which agrees well with the observed one. The peak discharge of $240 \mathrm{~m}^{3} \mathrm{~s}^{-1}$ computed by the Nye-Clarke model is in good agreement with the peak discharge estimated by the Clague Mathews formula. Since values of lake temperature and Manning roughness are unknown for any of the outburst years, the derived values mentioned above were used for further computations. These values are also in a range known from the literature (e.g. Clarke, 1982; Björnsson, 1992).

Based on these assumptions, Figure 7 shows the discharge curves of outbursts of Goësvatnet in 1991, 1961 and around 1938. It can be seen that the modelled peak discharges agree well with the computed peak discharges according to the Clague-Mathews relation in Table 2. This agreement confirms our assumption for lake temperature and Manning roughness. Furthermore it can be seen from Figure 7 that the computed duration of the outbursts has changed little since 1938 (from about $2 \mathrm{~d}$ to $1.3 \mathrm{~d}$ ). The change of the lake geometry from a cone-shaped to a paraboloid-shaped topography is equivalent to a reduction of peak discharge by about $10 \%$, whereas the reduced outlet tunnel length and the changed slope are equivalent to an increase of peak discharge by $17 \%$ and $30 \%$, respectively.

For the time period around 1991 a frequency of outbursts of about one per year is known from field observations. In 1991 the lake volume was reduced by $80 \%$ compared to 1938. This indicates that an outburst around 1938 happened about every 6 years whereas an outburst around 1961 happened about every 3 years.

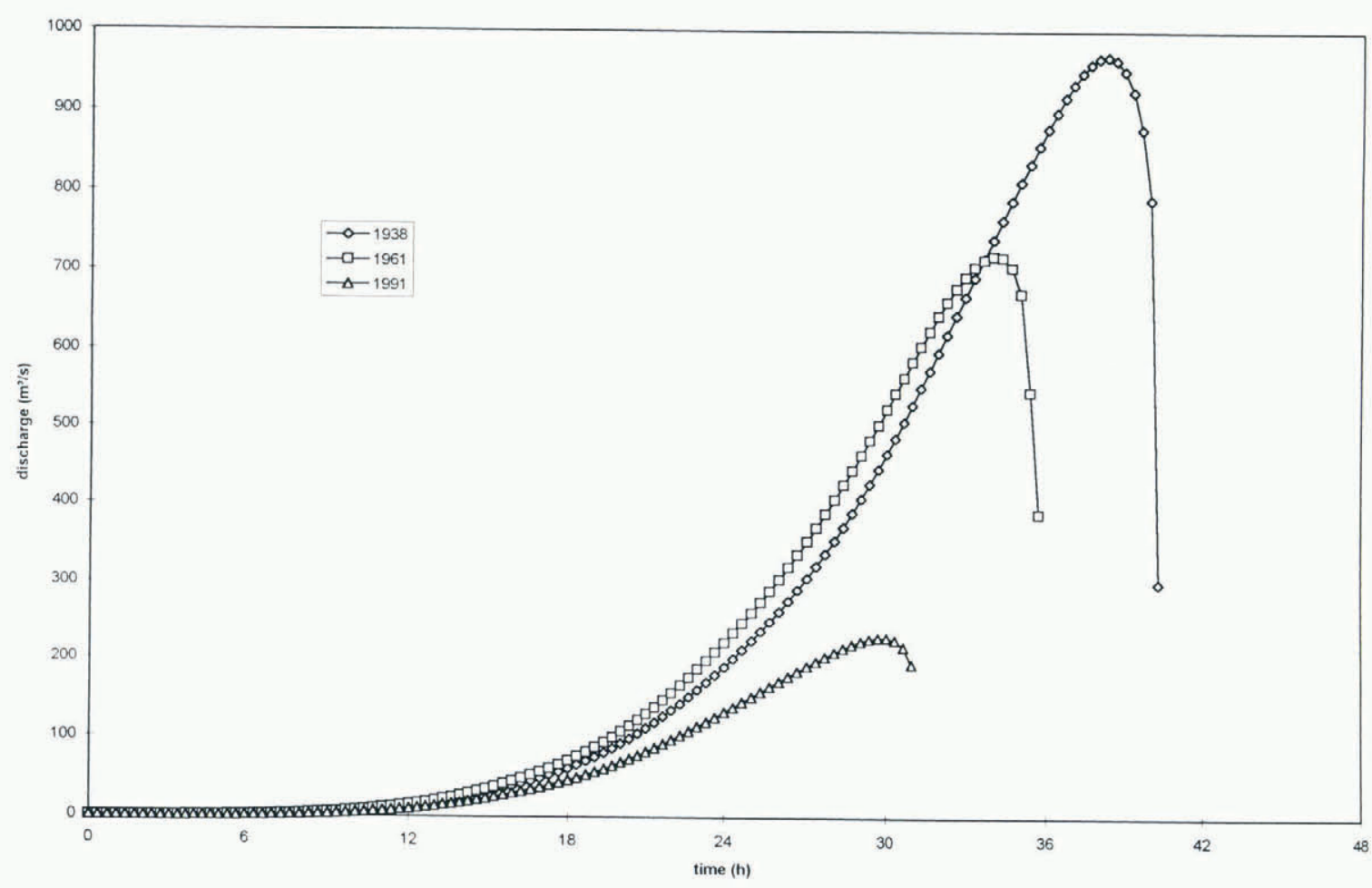

Fig. 7. Modelled outbursts of Goësvatnet in 1938, 1961 and 1991. 


\section{CONCLUSIONS}

To obtain the relation between the lost lake volume and the peak discharge during outburst floods we computed an unbiased regression equation which is relevant for outbursts with progressive enlargement of subglacial tunnels $\left(Q_{\max }=\right.$ $\left.72 V_{0}{ }^{0.70}\right)$. The derived equation is very similar to the original form of the Clague-Mathews formula. This similarity is the reason why the original Clague-Mathews formula worked well for many investigations.

Our investigation shows that outbursts of Goësvatnet start long before flotation of the ice dam is possible $\left(h_{\mathrm{i}} / h_{\mathrm{w}} \approx 0.6\right.$ ). The lowering of the damming ice masses of Gåsbreen reduced the water stored at the maximum stage in the lake of $80 \%$ and lowered peak discharge during outbursts from about $1000 \mathrm{~m}^{3} \mathrm{~s}^{-1}$ to $240 \mathrm{~m}^{3} \mathrm{~s}^{-1}$ in the period 1938-91. The computed peak discharge of $970 \mathrm{~m}^{3} \mathrm{~s}^{-1}$ for an outburst around 1938 confirms the assumption of Pillewizer (1939) that the sandur plain was flooded during an outburst at that time. Our field observations in 1991 and the computed peak discharge for 1991 show that during recent outbursts the sandur was not flooded. The change of the lake geometry from a cone-shaped to a paraboloid-shaped topography in the period 1938-91 is equivalent to a reduction of peak discharge by $10 \%$, whereas the reduction of the drainage tunnel length and the increased slope increase peak discharge by $17 \%$ and $30 \%$, respectively. The observations and computations of the outbursts of Goësvatnet fit well with the jökulhlaup activity shown by Evans and Clague (1994) in western Canada.

Finally, our study shows that a careful interpretation of old maps, aerial photos and field observations enables not only a qualitative description of historical and recent outburst floods but also an estimation of the peak discharge and a rough computation of the discharge curves by means of a physically based model.

\section{ACKNOWLEDGEMENTS}

This work was funded by the Austrian Science Foundation (project P8332-GEO). We would like to thank J. Jania, T. Niedzwiezc, the participants in the 1990-91 and 1991-92 Polish Spitsbergenexpedition and G. Vatne for their help with fieldwork and data acquisition. Comments by an anonymous referee made an important contribution to the aims of this paper.

\section{REFERENCES}

Baranowski, S. 1977. Subpolarne lodowce Spitsbergenu na tle limatu regionu. Uniwersytet Wroclaweski. Studia Geograficzne, 31, 94-95.

Björnsson, H. 1992. Jökulhlaups in Iceland: prediction, characteristics and simulation. Ann. Glaciol., 16, 95-106.

Brazdil, R. and 9 others. 1988. Results of investigations of the geographical research expedition Spitsbergen 1985. Brno, Univerzita J. E. Purkyně v Brně.

Clague, J.J. and W. H. Mathews. 1973. The magnitude of jökulhlaups. f. Glaciol., 12 (66), $501-504$.

Clarke, G. K. C. 1982. Glacier outburst floods from "Hazard Lake", Yukon Territory, and the problem of flood magnitude prediction. f. Glaciol., 28 (98), 32 l.

Costa, J. E. 1988. Floods from dam failures. In Baker, V. R., R. C. Kochel and P. C. Patton, eds. Flood geomorphology: Toronto, Ont., etc., John Wiley and Sons, $439-463$.

De Geer, G. 1925. Environs de la Station Russe d'hivernage par Gerard de Geer 1910. In Missions Scientifiques pour la Mesure d'un Arc de Meridien au Spitzberg. Entreprises en 1899 - 1902 (Stockholm), Tome 2.

Desloges, J. R., D. P. Jones and K. E. Ricker. 1989. Estimates of peak discharge from the drainage of ice-dammed Ape Lake, British Columbia, Canada. J. Glaciol., 35 (121), 349-354.

Evans, S. G. and J. J. Clague. 1994. Recent climatic change and catastrophic geomorphic processes in mountain environments. Geomorphology, 10 (1), $107-128$.

Fisher, D. 1973. Subglacial leakage of Summit Lake, British Columbia, by dye determinations. International Association of Scientific Hydrology Publication 95 (Symposium at Cambridge 1969 - Hydrology of Glaciers), 111-116.

Grzés, M. and M. Banach. 1984. The origin and evolution of the Goes lake in Sörkapp Land, Spitsbergen. Pol. Polar Res., 5 (3-4), $241-253$.

Haeberli, W. 1983. Frequency and characteristics of glacier floods in the Swiss Alps. Ann. Glaciol., 4, 85-90.

Liestol, O. 1955. Glacier-dammed lakes in Norway. Nor. Geogr. Tidsskr., 15 (34), 1955-1956, 122-149.

Norsk Polarinstitutt. 1990. Aerial photographs of Svalbard 1960/61 and 1990. Oslo, Norsk Polarinstitutt.

Nye, J. F. 1976. Water flow in glaciers: jökulhlaups, tunnels and veins. J. Glaciol., 17 (76), 181-207.

Pillewizer, W. 1939. Die kartographischen und gletscherkundlichen Ergebnisse der deutschen Spitzbergenexpedition 1938. Petermanns Geogr. Mitt. 238.

Polska Akademia Nauk, 1987. Hornsund, Spitsbergen. Warsaw, Polska Akademia Nauk. (Mapa Topograiczna, Scale 1:25,000.)

Röthlisberger, H. 1972. Water pressure in intra- and subglacial channels. $\mathcal{J}$. Glaciol., 11 (62), 177-203.

Russell, A.J. 1989. A comparison of two recent jökulhlaups from an icedammed lake, Sondre Stromfjord, West Greenland. J. Glaciol., 35 (120), $157-162$.

Schöner, M. and W. Schöner. 1996. Ergebnisse der Spitzbergenexpedition 1991. Geowissenschafiliche Mitteilungen. 42.

Spring, U. and K. Hutter. 1981. Numerical studies of jökulhlaups. Cold Reg. Sci. Technol., 4 (3), 227-244.

Thórarinsson, S. 1939. The ice dammed lakes of Iceland with particular reference to their values as indicators of glacier oscillations. Geogr. Ann., $21(3-4), 216-242$. 